\title{
The Effect of Vitamin C and E on Lipid Profile in People with Type 2 Diabetes Mellitus
}

\author{
Zahra Rafighi \\ Department of Diabetic, Kamkar Hospital \\ Bajack Street, Qom, Iran
}

Tel: 98-912-747-8858Ｅ-mail: z_rafighi@yahoo.com

Shahin Arab (Corresponding author)

Department of Clinical Biochemistry, Faculty of Medicine, Mazandaran University of Medical Sciences

Sari, Mazandaran, Iran

Tel: 98-911-323-3177_E-mail: shahinarab1@gmail.com

Rokia Mohd Yusof

Department of Nutrition and Dietetics, Faculty of Medicine and Health Science, University Putra Malaysia 43400 UPM, Serdang, Selangor, Malaysia

Atena Shiva

Department of Pathology, Oral and Maxillofacial Pathology Unit, Faculty of Dentistry, Ferdowsi University Mashhad, Khorasan, Iran

Received: April 18, 2011 Accepted: May 6, 2011 doi:10.5539/gjhs.v3n2p69

Source of Support: Mt grant 258

Conflict of Interest: None declared

\begin{abstract}
Introduction: Diabetes mellitus is one of the most common metabolic disorders that cause micro- and macro-vascular complications. Because of cardiovascular disease is common in type 2 diabetes mellitus (T2DM), lipid abnormalities should be evaluated in diabetes patients. Aim: Since vitamin C, E are known for their helpful effects on plasma lipids and glycated hemoglobin (HbA1c), we evaluated the effect of these vitamins on blood glucose, plasma lipids in individuals with type 2 diabetes mellitus. Methods: The study was carried out in 170 T2DM on consumption of vitamin C, E, combination of C \& E and placebo. The subjects comprised of two main groups, supplementation and placebo group which supplementation group consists of 3 sub-groups. Each subgroup received three capsules per day for a period of three months. HbA1c, glucose and lipid profile were determined in baseline and after three months with receiving supplement. Results: A significant decrease $(p<0.001)$ in FBS, TG, LDL, cholesterol and HbA1c was seen in the supplemented groups after three months. Conclusion: This study demonstrated that patients with T2DM after three months consumption of vitamins C, E and C\&E showed significantly lowered hypertension and improved insulin action and decrease lipid profile.
\end{abstract}

Keywords: T2DM, Vitamin C, Vitamin E, Hyperlipidemia

\section{Introduction}

Diabetes mellitus is a heterogeneous group of metabolic diseases that is characterized by chronic hyperglycemia and instability in carbohydrate, lipid, and protein metabolism resulting from defects in insulin secretion and/or insulin action (Abdel-Rahman, 2011) which leads to many disorders, mainly cardiovascular disease and early 
death. Most patients with diabetes have lipid metabolism disorders; most common forms are decreased high density lipoprotein (HDL-C) and increased triglyceride, cholesterol and LDL-c. High doses of vitamins C and E have been shown to decrease blood glucose, plasma cholesterol and triglyceride in T2DM patients (Chen et al., 2006). LDL-c particles are small and dense in T2DM and are susceptible to oxidation and finally lead to atherosclerosis events. Vitamin E is a lipid soluble antioxidant and protects LDL-c particles from oxidative attack (Afkhami et al., 2009). Antioxidants may help reduce the risk of heart disease and other complications in people with diabetes (Devaraj and jialal, 2006).

Moreover, Vitamin C and E are important antioxidant in humans, able of scavenging oxygen-derived free radicals, improved hyperlipidemia and decreased blood pressure (Caballero, 2004). Vitamin C is structurally similar to glucose and can replace it in many chemical reactions, and thus is effective in prevention of non-enzymatic glycosylation of proteins. Several studies showed increased oxidative stress, and decreased basal vitamin C and E levels in diabetic patients (American Diabetes Association., 2009). Type 2 diabetes mellitus, hypertension and dyslipidemia are associated with insulin resistance and an increased risk of coronary heart disease. Therefore, reducing fat intake, increasing antioxidants, particularly vitamins $\mathrm{C}$ and $\mathrm{E}$ intake, should be encouraged (Kaviarasan et al., 2005).

\section{Material and method}

\subsection{Subjects}

170 individuals with T2DM, from Research Institute of Endocrinology and Metabolism, Iran University of Medical Sciences (IUMS) were recruited in this study. Patients with T2DM were selected base on fasting blood glucose more than $126 \mathrm{mg} / \mathrm{dL}(7.0 \mathrm{mmol} / \mathrm{L})$. $\mathrm{HbA}_{1} \mathrm{c}$ equal or more than $6.5 \mathrm{mg} / \mathrm{dL}$, no treatment by insulin therapy, only treatment by glucose lowering medicines, not currently taking vitamin and/or mineral supplements. Patients with history of acute and chronic inflammatory illness, permanent diseases occlusive, cardiovascular disease, renal failure, age range 30>age $>65$ years old and with BMI $<25\left(\mathrm{~kg} / \mathrm{m}^{2}\right)$ were excluded from the study.

\subsection{Sampling population}

The subjects of this study comprised of two main groups, supplementation and placebo group, consist of 3 sub-groups, which each supplementation group received three capsules per day for a period of three months. Each capsule contains one of the following preparations and hence determined the corresponding groups:

Vitamin C group (266.7 mg), vitamin E group (300IU), vitamin C+E group (300IU+266.7mg) and placebo group (placebo has been made of starch). The supplement and placebo capsules looked identical and were specially prepared for this study by Darou-Pakhsh (Tehran, Iran).Randomized assignment into the four groups was by proportional randomization method using a table of random numbers generated by Microsoft Excel. For example, if the sequence of the list generated by the computer is ABEDCCBBEDEA, then the first subject was randomized to the supplementation with vitamin $C$ group, vitamin $\mathrm{E}$ group, vitamin $\mathrm{C}+\mathrm{E}$ group, and placebo group until all the subjects were assigned to groups. After three months of supplementation with vitamin C, E and $\mathrm{C} \& \mathrm{E}$, patients were examined again and the tests repeated.

\subsection{Blood sampling and laboratory measurements}

Blood samples from people with T2DM were taken under fasting condition into tubes containing EDTA. About $20 \mathrm{ml}$ of fasting venous blood sample was taken in the morning after 8 to 10 hours of an overnight fast. The plasma were prepared, aliquoted and stored at $-80^{\circ} \mathrm{C}$ until the analysis were carried out.

\subsection{Routine parameters}

$\mathrm{HbA}_{1} \mathrm{C}$ was measured by HPLC using commercial kit (Sigma, USA). The concentration of ascorbic acid (vitamin C) in the plasma was determined by spectrophotometric using phenyl hydrazine indicator (Sigma, USA) as described by (Ahmed et al., 2004). The vitamin E concentration in plasma was determined using high performance liquid chromatography (HPLC, UK). Lipid profile (cholesterol, LDL, triglyceride, HDL) was evaluated by enzymatic method (Roche diagnostic, USA).

\subsection{Statistical analysis}

All data were analyzed using the statistical packages for social science (SPSS) for window, version 16.0 (SPSS Inc., Chicago, IL, USA) and all data were expressed as mean \pm SD. The statistics analyses were determined based on the research objectives and hypothesis of the research. Energy and others nutrients (in particular, vitamin C, E) intake are reported as the percentages, mean and standard deviation. Statistical significance by treatment was assessed for comparison of the changes in risk factors T2DM and antioxidant vitamins baseline and after three months within groups by paired-sample t-test and between four groups by one-way analysis 
variance (ANOVA), has been compared. P values lower than 0.05 were considered to be significant.

\subsection{Ethical issues}

The study was approved by the Ethic Committee of Faculty of Medicine and Health Science, University Putra Malaysia (UPM), and Iran University of Medical Sciences (IUMS). The informed consent was obtained from the subjects before participating in this study.

\section{Results}

\subsection{Descriptive and paired-sample t-test}

Mean age of 170 patients (84 male, 86 female) was 53.82 \pm 5.26 years (range: 30-65) in both gender. Of these, 44 patients underwent treatment with vitamin C, 43 patients vitamin E, and 43 patients treatment with vitamin C and $\mathrm{E}$, and 40 patients received placebo. There were no significant differences in body mass index (BMI), waist circumference (WC), hip circumference (HC), and waist hip ratio (WHR) between groups, before and after treatment. Systolic and diastolic blood pressure parameters showed significant differences between the all supplement groups before and after treatment $(p<0.05)$. Consumption of vitamin $\mathrm{C}$, E, and $\mathrm{E} \& \mathrm{C}$ resulted in significant changes in plasma levels of FBS and HbA1c $(P<0.05 \&<0.001)$, but consumption of placebo did not show any changes in these parameters.

The mean values of LDL-c, total cholesterol and triglyceride levels after three months in receiving vitamin C, E and C\&E groups were significantly $(p<0.001)$ higher than baseline groups. The mean values of HDL-c levels after three months in vitamin C, E and C \& E groups were significantly $(p<0.001)$ lower than baseline in patients with T2DM.

\section{Discussion}

Hyperglycemia has been established as a necessary factor in the development of diabetic complications (Rosen et al., 2001). T2DM disease can be lead to microvascular and cardiovascular complication (Jay et al., 2006). The results of this study showed the relationship of supplementation vitamin $C$ and $E$ to improve hyperglycemia and hyperlipidemia conditions.

The present study demonstrated that in people with diabetes, increased production of triglycerides and LDL cholesterol occurred in association with reduced levels of HDL cholesterol. This was in accordance with Budin et al. (2009), who studied that both lipid accumulations particularly triglycerides and reduction in antioxidant activity contributed to the development of oxidative stress in diabetes. Hyperglycemia was found to promote lipid peroxidation of low density lipoprotein (LDL) by a superoxide-dependent pathway resulting in the generation of free radicals (Giacco and Brownlee, 2010). It appears that hyperglycemia could be an initiation step for induction of oxidative stress (Al-Rawi, 2011). Vitamins $\mathrm{E}$ and $\mathrm{C}$ have an important function in glucose metabolism (Martini et al., 2010). Reduced levels of antioxidants such as vitamin C and E occurred in people with diabetes (Ceriello et al., 1998).

In this study, oral administration of vitamins $\mathrm{E}$ and $\mathrm{C}$ for three months improved the picture of hyperlipidemia and hyperglycemia in people with diabetes (Table 2). Our results were agreement with Rahimia et al., (2005) study who indicated that the use of antioxidants reduces oxidative stress in diabetes. Both vitamin $\mathrm{C}$ and vitamin E decreased lipid peroxidation and increased the activities of antioxidant enzymes in T2DM, which was agreement with Kedziora- Kornatowskaa et al., (2003) study in rats. Vitamin C was found to be significantly decreasing the elevated levels of glucose, cholesterol, triglycerides and low-density lipoprotein (LDL) in T2DM (Badr et al., 2011). On the other hand, a recent study by de Oliveira et al. (2011) suggested that vitamin E supplementation alone, did not affect on lipid profile of type $2 \mathrm{DM}$.

Paolisso et al. (2007) also reported beneficial effects of oral vitamin C (1000 mg/day for 4 months) on glucose, lipid metabolism, and free radicals in T2DM. In this work the efficiency of vitamin E against lipid peroxidation was apparent through the reduction of the susceptibility of erythrocytes to hydrogen peroxide-induced lipid peroxidation (Abed et al., 2001), and a potent lipophilic agent that forms an important scavenger component of the cell membrane. It may protect the safety of the membrane by reducing the production of lipid peroxides (Meagher et al., 2001). Other study suggested that vitamin E administration is associated with decreased glycosylation of hemoglobin, some serum proteins, and decreased susceptibility of LDL to oxidation. Vitamin C is required for regeneration of $\alpha$-tocopherol (vitamin E) and may thus prevent LDL oxidation, and transport of $\alpha$-tocopherol in HDL may enhance and preserve these protective antioxidant effects of HDL. Vitamin E supplementation may have special benefits in preserving HDL antioxidant function in diabetic subjects (Gowri et al., 2009).It has been shown decreased levels of lipid profile, lipid peroxidation and free radical production by vitamin E and C supplementation (Upritchard et al., 2008; Jialal et al., 2006). 


\section{Conclusion}

The present study provides evidence that hyperglycemia plays a significant role in hyperlipidemia. Supplementation of vitamins C and E to T2DM might support improves endogenous antioxidant capacity due to reducing blood glucose and lipid metabolites, and they may play a role in preventing cardiovascular diseases in Type 2 diabetes.

\section{Acknowledgements}

We would like to thank Research Institute of Endocrinology and Metabolism, Iran University of Medical Sciences (IUMS), for financial support; and referring patients.

\section{References}

Abdel-Rahman, Z. (2011). The effects of antioxidants supplementation on haemostatic parameters and lipid profiles in diabetic rats. Journal of American Science, 7 (3), 835-840.

Abed, Shalata \& Peter, M. Neumann. (2001). Exogenous ascorbic acid (vitamin C) increases resistance to salt stress and reduces lipid peroxidation. J. Experimental Botany, 52 (364), 2207-2211.

Afkhami-Ardekani, M., Mohiti, J., Amirchaghmaghi, E., \& Modarresi, M. (2009). The effect of vitamins C and E supplementation on insulin level, $\mathrm{HbA}_{1} \mathrm{C}$ and blood glucose in type 2 diabetic patients. J Beh Kerm Univ Med Sci, 11, 12-8.

Afkhami-Ardekani, M. \& Shojaoddiny-Ardekani, M. (2007). Effect of vitamin C on blood glucose, serum lipids \& serum insulin in type 2 diabetes patients. Indian J Med Res, 126, 471-474.

Ahmed, L., Islam, S. K. N., Khan, M. N. I., Huque, S., \& Ahsan, M. (2004). Antioxidant Micronutrient Profile (Vitamin E, C, A, Copper, Zinc, Iron) of Colostrum: Association with Maternal Characteristics. Journal of Tropical Pediatrics, 50 (6), 357-358. http://dx.doi.org/10.1093/tropej/50.6.357

American Diabetes Association. (2009). Standards of medical care in diabetes (Position Statement). Diabetes Care, 32 (Suppl. 1), S13-S61.

Badr, G., Bashandy, S., Ebaid, H., Mohany, M., \& Sayed, D. (2011). Vitamin C supplementation reconstitutes polyfunctional T cells in streptozotocin-induced diabetic rats. Eur. Nutr, 25.

Budin Balkis, S., Othman, F., Louis, S. R., Abu Bakar, M., Radzi, M., Osman, K., Das, S., \& Mohamed, J. (2009). Effect of alpha lipoic acid on oxidative stress and vascular wall of diabetic rats. Rom J. Morphol. Embryol, 50 (1), 23-30.

Caballero, A. E. (2004). Endothelial dysfunction, inflammation, and insulin resistance: a focus on subjects at risk for type 2 diabetes. Curr DiabRep, 4, 237-246.

Ceriello, A., Bortolotti, N., \& Crescentini, A. (1998). Antioxidant defences are reduced during the oral glucose tolerance test in normal and non-insulin-dependent diabetic subjects. Eur. J. Clin Invest, 28, 329. http://dx.doi.org/10.1046/j.1365-2362.1998.00295.x

Chen, H., Karne, R. J., Hall, G., Campia, U., Panza, J. A., \& Cannon, R. O. (2006). High-dose oral vitamin C partially replenishes vitamin $C$ levels in patients with type 2 diabetes and low vitamin $C$ levels but does not improve endothelial dysfunction or insulin resistance. Am J Physiol Heart Circ Physiol, 290, H137-145. http://dx.doi.org/10.1152/ajpheart.00768.2005

Devaraj, S. \& Jialal, I. (2006). Low-density lipoprotein post secretory modification, monocyte function, and circulating adhesion molecules in type 2 diabetic patients with and without macro vascular complications: the effect of alpha-tocopherol supplementation. Circulation, 102, 191-196.

Giacco, F. \& Brownlee, M. (2010). Oxidative stress and diabetic complications. Circ. Res, 107 (9), 1058-70. http://dx.doi.org/10.1161/CIRCRESAHA.110.223545

Gowri, M. S., Van der Westhuyzen, D. R., Bridges, S. R., \& Anderson, J. W. (2009). Decreased protection by HDL from poorly controlled type 2 diabetic subjects against LDL oxidation may be due to its abnormal composition. Atheroscler Thromb Vasc Biol, 24, 816-23.

Jay, D., Hitomi, H., Griendling, K. K. (2006). Oxidative stress and diabetic cardiovascular complications. Free Radic. Biol. Med, 40,183-192. http://dx.doi.org/10.1016/j.freeradbiomed.2005.06.018

Kaviarasan, K., Arjunan, M. M., \& Pugalendi, K. V. (2005). Lipid profile, oxidant-antioxidant status and glycoprotein components in hyperlipidemia patients with/without diabetes. Clin. Chim. Acta, 362, 49-56. http://dx.doi.org/10.1016/j.cccn.2005.05.010 
Kedziora-Kornatowska, K., Szram, S., Kornatowski, T., Szadujkis-Szadurski, L., Kedziora, J., \& Bartosz, G. (2003). Effect of Vitamin E and Vitamin C Supplementation on antioxidative state and renal Glomerular basement membrane thickness in Diabetic Kidney. Experimental nephrol, 95 (4), 34-43.

Meagher, E. A., Barry, O. P., Lawson, J. A., Rokach, J., \& FitzGerald, G. A. (2001). Effects of vitamin E on lipid peroxidation in healthy persons. JAMA, 285, 1178-1182.

Oliveira, E. P. D., Manda, R., Torezan, G. A., Corrente, G. E., \& Burini, R. C. (2011). Dietary, Anthropometric, and Biochemical Determinants of Plasma High-Density Lipoprotein-Cholesterol in Free-Living Adults Hindawi Publishing Corporation Cholesterol, Article ID 851750, 7.

Rahimia, R., Nikfara, S., Larijanib, B., \& Abdollahia, M. (2005). A review on the role of antioxidants in the management of diabetes and its complications. Biomedecine \& Pharmacotherapy, 59 (7), 365-373. http://dx.doi.org/10.1016/j.biopha.2005.07.002

Paolisso, G., Balbi, V., Volpe, C., Varricchio, G., Gambardella, A., Saccomanno, F., Ammendola, S., \& Varricchio, M. (2007). Metabolic benefits deriving from chronic vitamin $C$ supplementation in aged non-insulin dependent diabetics. J Am Coll Nutr, 14, 387-392.

Upritchard, J. E., Sutherl, W. H. F., \& Mann, J. I. (2008). Effect of supplementation, vitamin E and vitamin C on LDL oxidation and products of inflammatory activity in type 2 diabetes. Diabetes Care, 23, 733-738. http://dx.doi.org/10.2337/diacare.23.6.733

Rösen, P., Nawroth P. P., King, G., Möller, W., Tritschler, H. J., \& Packer L. (2001). The role of oxidative stress in the onset and progression of diabetes and its complications: a summary of a Congress Series sponsored by UNESCO-MCBN, the American Diabetes Association and the German Diabetes Society. Diabetes Metab, Res. Rev, 17, 189-212.

Table 1. Anthropometric measurements of the subjects at baseline and after three months

\begin{tabular}{|c|c|c|c|c|c|c|c|c|c|c|c|c|}
\hline & \multicolumn{2}{|c|}{$\begin{array}{l}\text { Vitamin C } \\
\text { groups }\end{array}$} & & \multicolumn{2}{|c|}{$\begin{array}{l}\text { Vitamin E } \\
\text { groups }\end{array}$} & & \multicolumn{2}{|c|}{$\begin{array}{l}\text { Vitamin } C+E \\
\text { groups }\end{array}$} & & \multicolumn{2}{|c|}{ Placebo groups } & \\
\hline $\begin{array}{c}\text { Variable } \\
\mathrm{s}\end{array}$ & $\begin{array}{c}\text { Baseli } \\
\text { ne }\end{array}$ & $\begin{array}{c}\text { After } \\
\text { three } \\
\text { month } \\
\text { S }\end{array}$ & $P$ & $\begin{array}{c}\text { Baseli } \\
\text { ne }\end{array}$ & $\begin{array}{c}\text { After } \\
\text { three } \\
\text { month } \\
\text { s }\end{array}$ & $P$ & $\begin{array}{c}\text { Baseli } \\
\text { ne }\end{array}$ & $\begin{array}{c}\text { After } \\
\text { three } \\
\text { month } \\
\text { s }\end{array}$ & $P$ & Baseline & $\begin{array}{c}\text { After } \\
\text { three } \\
\text { month } \\
\text { S }\end{array}$ & $p$ \\
\hline Number & 44 & ---- & & 43 & & & 43 & & & 40 & & \\
\hline Gender & & & - & & & - & & & & & & - \\
\hline Female & 12 & & - & 27 & & - & 15 & & & 27 & & - \\
\hline Male & 27 & & - & 16 & & - & 28 & & & 13 & & - \\
\hline $\begin{array}{c}\text { Age } \\
\text { (years) }\end{array}$ & $\begin{array}{l}54.40 \\
\pm 4.74 \\
\end{array}$ & & & $\begin{array}{l}52.47 \\
\pm 5.53 \\
\end{array}$ & & & $\begin{array}{l}51.26 \\
\pm 5.83 \\
\end{array}$ & & & $\begin{array}{c}51.09 \pm 7 \\
.83 \\
\end{array}$ & & \\
\hline $\begin{array}{l}\text { Systolic } \\
\text { Bp(mmH } \\
\text { g) } \\
\text { Diastolic } \\
\text { Bp(mmH } \\
\text { g) }\end{array}$ & $\begin{array}{c}136.5 \\
9 \pm 29 . \\
07 \\
81.37 \\
\pm 91.72\end{array}$ & $\begin{array}{c}122.9 \\
5 \pm 16 . \\
08 \\
79.69 \\
\pm 12.4 \\
8\end{array}$ & $\begin{array}{c}0.00 \\
8 \\
0.00 \\
9\end{array}$ & $\begin{array}{c}132.7 \\
4 \pm 28 . \\
59 \\
99.43 . \\
49 \pm 12 \\
.15\end{array}$ & $\begin{array}{c}123.1 \\
1 \pm 25 . \\
08 \\
92.30 \\
\pm 9.64\end{array}$ & $\begin{array}{c}0 . \\
00 \\
6 \\
0 . \\
00 \\
4\end{array}$ & $\begin{array}{c}141.7 \\
6 \pm 15 \\
45 \\
82.59 \\
\pm 9.48\end{array}$ & $\begin{array}{c}126.1 \\
2 \pm \\
9.45 \\
78.32 \\
\pm 10.2 \\
1\end{array}$ & $\begin{array}{c}0 . \\
00 \\
3 \\
0 . \\
01 \\
7\end{array}$ & $\begin{array}{c}144.99 \pm \\
26.41 \\
89.97 \pm 1 \\
3.09\end{array}$ & $\begin{array}{c}145.1 \\
9 \pm 27 \\
46 \\
89.27 \\
\pm 14.2 \\
9\end{array}$ & $\begin{array}{c}0 . \\
23 \\
2 \\
0 . \\
32 \\
2 \\
\end{array}$ \\
\hline$\underset{\left(\mathrm{kg} / \mathrm{cm}^{\underline{2}}\right)}{\mathbf{B M I}}$ & $\begin{array}{r}30.43 \\
\pm 3.91 \\
\end{array}$ & $\begin{array}{r}29.45 \\
\pm 3.59 \\
\end{array}$ & $\begin{array}{c}0.06 \\
1\end{array}$ & $\begin{array}{r}30.86 \\
\pm 3.76 \\
\end{array}$ & $\begin{array}{r}30.12 \\
\pm 3.49 \\
\end{array}$ & $\begin{array}{c}0 . \\
12 \\
1\end{array}$ & $\begin{array}{l}33.17 \\
\pm 3.32\end{array}$ & $\begin{array}{l}30.85 \\
\pm 2.45\end{array}$ & $\begin{array}{c}0 . \\
05 \\
9\end{array}$ & $\begin{array}{c}29.29 \pm 3 \\
.17\end{array}$ & $\begin{array}{l}29.95 \\
\pm 3.07\end{array}$ & $\begin{array}{c}0 . \\
18 \\
1\end{array}$ \\
\hline $\mathbf{W C}(\mathrm{cm})$ & $\begin{array}{r}87.40 \\
\pm 9.80 \\
\end{array}$ & $\begin{array}{r}88.50 \\
\pm 9.71 \\
\end{array}$ & $\begin{array}{c}0.29 \\
1\end{array}$ & $\begin{array}{c}89.87 \\
\pm 12.1 \\
2\end{array}$ & $\begin{array}{c}95.23 \\
\pm 11.3 \\
2 \\
\end{array}$ & $\begin{array}{c}0 . \\
54 \\
3\end{array}$ & $\begin{array}{c}93.15 \\
\pm 15.6 \\
3\end{array}$ & $\begin{array}{c}93.23 \\
\pm 14.6 \\
7\end{array}$ & $\begin{array}{c}0 . \\
65 \\
4\end{array}$ & $\begin{array}{c}96.72 \pm 1 \\
1.31 \\
\end{array}$ & $\begin{array}{c}95.69 \\
\pm 13.6 \\
7\end{array}$ & $\begin{array}{c}0 . \\
07 \\
1\end{array}$ \\
\hline $\mathrm{HC}(\mathrm{cm})$ & $\begin{array}{c}95.28 \\
\pm 11.4 \\
1\end{array}$ & $\begin{array}{c}99.39 \\
\pm 10.8 \\
7 \\
\end{array}$ & $\begin{array}{c}0.32 \\
1\end{array}$ & $\begin{array}{c}99.39 \\
\pm 10.8 \\
7 \\
\end{array}$ & $\begin{array}{c}97.98 \\
\pm 10.8 \\
7 \\
\end{array}$ & $\begin{array}{c}0 . \\
56 \\
4 \\
\end{array}$ & $\begin{array}{c}94.85 \\
\pm 10.8 \\
9\end{array}$ & $\begin{array}{c}96.77 \\
\pm 11.7 \\
6\end{array}$ & $\begin{array}{c}0 . \\
76 \\
2 \\
\end{array}$ & $\begin{array}{c}99.39 \pm 1 \\
0.87 \\
\end{array}$ & $\begin{array}{c}100.6 \\
8 \pm 7.8 \\
5\end{array}$ & $\begin{array}{c}0 . \\
51 \\
6 \\
\end{array}$ \\
\hline WHR & $\begin{array}{l}0.89 \pm \\
0.046\end{array}$ & $\begin{array}{c}0.93 \pm \\
0.34 \\
\end{array}$ & $\begin{array}{c}0.54 \\
3\end{array}$ & $\begin{array}{l}0.98 \pm \\
0.083\end{array}$ & $\begin{array}{l}0.99 \pm \\
0.441\end{array}$ & $\begin{array}{c}0 . \\
68 \\
1\end{array}$ & $\begin{array}{l}0.99 \pm \\
0.059\end{array}$ & $\begin{array}{l}0.99 \pm \\
0.076\end{array}$ & $\begin{array}{c}0 . \\
61 \\
2\end{array}$ & $\begin{array}{c}0.96 \pm 0 . \\
066\end{array}$ & $\begin{array}{c}0.98 \pm \\
0.74\end{array}$ & $\begin{array}{c}0 . \\
31 \\
2\end{array}$ \\
\hline
\end{tabular}

Note: Data were presented using sample paired $t$ test, and were given as mean \pm SD. BMI $=$ Body mass index; WHR=Waist hip ratio; WC=Waist circumferences; HC=Hip circumference; SD=Standard deviation. 
Table 2. Biochemical parameters of the subjects at baseline and after three months

\begin{tabular}{|c|c|c|c|c|c|c|c|c|}
\hline \multirow[b]{2}{*}{ Variables } & \multicolumn{2}{|c|}{ Vitamin C groups } & \multicolumn{2}{|c|}{ Vitamin E groups } & \multicolumn{2}{|c|}{ Vitamin C \& E group } & \multicolumn{2}{|c|}{ Placebo groups } \\
\hline & baseline & $\begin{array}{l}\text { After thre } \\
\text { months }\end{array}$ & baseline & $\begin{array}{l}\text { After three } \\
\text { months }\end{array}$ & baseline & $\begin{array}{l}\text { After three } \\
\text { months }\end{array}$ & baseline & $\begin{array}{l}\text { After three } \\
\text { months }\end{array}$ \\
\hline FBS(mg/dl) & $\begin{array}{l}153.73 \pm 2 € \\
9\end{array}$ & $\begin{array}{l}135.45 \pm \\
22.18^{\mathrm{b}}\end{array}$ & $\begin{array}{l}161.91 \pm 39 \\
.78\end{array}$ & $\begin{array}{l}134.44 \pm 26 \\
.94^{\mathrm{b}}\end{array}$ & $\begin{array}{l}147.70 \pm \\
14.85\end{array}$ & $\begin{array}{l}140.58 \pm 2 \\
1.00^{\mathrm{a}}\end{array}$ & $\begin{array}{l}149.78 \pm 34 \\
.58\end{array}$ & $\begin{array}{l}143.55 \pm 37 . \\
42\end{array}$ \\
\hline HbA1c (\%) & $\begin{array}{l}8.48 \pm 1 \\
03\end{array}$ & $\begin{array}{l}6.99 \pm .8 \\
4^{b}\end{array}$ & $8.12 \pm 1.09$ & $\begin{array}{l}7.18 \pm 1.10 \\
\text { b }\end{array}$ & $\begin{array}{l}9.05 \pm .8 \\
4\end{array}$ & $\begin{array}{l}6.84 \pm .76 \\
b\end{array}$ & $\begin{array}{l}8.302 \pm 1.3 \\
5\end{array}$ & $8.02 \pm 1.42$ \\
\hline TC (mg/dl) & $\begin{array}{l}201.95 \pm \\
44.03\end{array}$ & $\begin{array}{l}173.88 \pm \\
38.06^{\mathrm{b}}\end{array}$ & $\begin{array}{l}208.91 \pm 36 \\
.58\end{array}$ & $\begin{array}{l}166.32 \pm 30 \\
.41^{\mathrm{b}}\end{array}$ & $\begin{array}{l}227.42 \pm \\
39.41\end{array}$ & $\begin{array}{l}167.67 \pm 2 \\
4.49^{\mathrm{b}}\end{array}$ & $\begin{array}{l}180.48 \pm 46 \\
.25\end{array}$ & $\begin{array}{l}171.65 \pm 31 . \\
22\end{array}$ \\
\hline LDL(mg/dl) & $\begin{array}{l}136.59 \pm \\
29.07\end{array}$ & $\begin{array}{l}102.95 \pm \\
28.08^{\mathrm{b}}\end{array}$ & $\begin{array}{l}132.74 \pm 28 \\
.59\end{array}$ & $\begin{array}{l}92.11 \pm 25 . \\
08^{\mathrm{b}}\end{array}$ & $\begin{array}{l}155.44 \pm \\
18.70\end{array}$ & $\begin{array}{l}95.53 \pm 15 \\
.14^{\mathrm{b}}\end{array}$ & $\begin{array}{l}122.65 \pm 32 \\
.05\end{array}$ & $\begin{array}{l}119.12 \pm 29 . \\
94\end{array}$ \\
\hline HDL(mg/dl) & $\begin{array}{l}38.11 \pm 4 . \\
66\end{array}$ & $\begin{array}{l}39.88 \pm 6 \\
.39^{\mathrm{a}}\end{array}$ & $\begin{array}{l}41.16 \pm 4.9 \\
9\end{array}$ & $\begin{array}{l}46.00 \pm 3.7 \\
0^{\mathrm{b}}\end{array}$ & $\begin{array}{l}37.16 \pm 4 \\
.38\end{array}$ & $\begin{array}{l}45.72 \pm 3 . \\
80^{\mathrm{b}}\end{array}$ & $\begin{array}{l}38.17 \pm 4.4 \\
6\end{array}$ & $39.95 \pm 4.64$ \\
\hline TG (mg/dl) & $\begin{array}{l}229.34 \pm \\
68.00\end{array}$ & $\begin{array}{l}166.86 \pm \\
51.73^{\mathrm{b}}\end{array}$ & $\begin{array}{l}199.49 \pm 62 \\
.15\end{array}$ & $\begin{array}{l}172.30 \pm 61 \\
.60^{\mathrm{b}}\end{array}$ & $\begin{array}{l}244.86 \pm \\
65.30\end{array}$ & $\begin{array}{l}171.37 \pm 4 \\
3.22^{\mathrm{b}}\end{array}$ & $\begin{array}{l}212.18 \pm 84 \\
.70\end{array}$ & $\begin{array}{l}195.00 \pm 74 . \\
01\end{array}$ \\
\hline
\end{tabular}

Note: Data were presented using sample paired t test., ${ }^{a} p<0.05,{ }^{b} p<0.001$ after three months supplementation versus baseline. FBS= Fasting blood glucose,

$\mathrm{TC}=$ Total cholesterol, $\mathrm{LDL}=$ Low density lipoprotein, $\mathrm{HDL}=$ high density lipoprotein, $\mathrm{TG}=$ Triglyceride. 